\title{
BIODIESEL FROM MICROALGAE: COMPLEMENTARITY IN A FUEL DEVELOPMENT STRATEGY
}

\author{
Lewis M. Brown \\ National Renewable Energy Laboratory \\ 1617 Cole Blvd. \\ Golden, CO 80401
}

\begin{abstract}
Biodiesel produces fewer pollutants than petroleum diesel, and is virtually free of sulfur. These properties make biodiesel an attractive candidate to facilitate compliance with the Clean Air Act Amendments of 1990 (CAAA). This fuel is ordinarily considered to be derived from oilseeds, but an essentially identical biodiesel can be made from microalgae. This technology is complementary to ongoing efforts to grow lignocellulosic biomass in areas with good soil and water resources, because microalgae are projected to be grown in those areas where lignocellulosics or oilseed crops will not grow well (desert southwestern United States and other areas with poor soils). Another area where microalgae are complementary to other energy crops is in quad potential and market readiness. The potential contribution of oilseeds and waste fats to the energy supply is much less than 1 quadBTU/yr ( $\left.1 \mathrm{EJ}^{*} / \mathrm{yr}\right)$. However, oilseed biodiesel can be made available quickly, thus helping to solve local air pollution problems over the short term and establishing an early market niche for biodiesel. Microalgal biodiesel would come on line later after further technology development to fulfill the multi-quad demand for diesel.
\end{abstract}

\section{Biodiesel Definition}

The esters derived from oils and fats from renewable biological sources are defined as biodiesel (Clements 1992). Typically, oils from microalgae, animal fats, and oilseed crops are chemically very similar, if not identical.

${ }^{*} \mathrm{EJ}=10^{18} \mathrm{~J}$ oules 


\section{Market Analysis}

The total energy demand in the United States was approximately 81 quadBtu/yr in 1991 (1 quadBtu=1EJ/yr) (Energy Information Administration 1992). Of that total 3.7 quadBtu/yr was diesel fuel used in the transportation sector. Biodiesel has particular advantages when used in that sector because of environmental concems with petroleum diesel. Biodiesel is a cleaner fuel than petroleum diesel. It is virtually free of sulfur, thereby eliminating the production of sulfur oxides during combustion. Emissions of hydrocarbons, carbon monoxide, and particulates during combustion are also significantly reduced, in comparison to emissions from petroleum diesel (Raymer and Van Dyne 1992a). Biodiesel is also non-toxic and biodegradable (Van Dyne and Raymer 1992b). It is miscible with petroleum diesel and can be used in conventional diesel engines. These properties make biodiesel useful in facilitating compliance with the CAAA of 1990. Biodiesel provides similar energy content and power output as petroleum-based diesel fuel while reducing emissions. Biodiesel's low pollutant emissions can be extremely useful in Environmental Protection Agency (EPA) non-attainment areas, which are typically central cities with acute local air pollution problems. Buses and other fleet vehicles running on biodiesel have the potential to make a major impact in these markets.

The CAAA provides significant opportunity for the replacement of conventional diesel fuel with biodiesel. In 1993, clean diesel fuel regulations take effect, requiring the sulfur content of diesel used in highway transport trucks to be limited to $0.05 \%$, for a reduction of $90 \%$. This requirement will affect roughly $80 \%$ of the distillate fuel consumed in the transportation sector (EIA 1993). Assuming that the percentage of diesel fuel affected remains constant (i.e., $80 \%$ ), the reformulation is 24.1 billion gallons ( 91.0 billion liters) in 1995, 26.5 billion gallons (100 billion liters) in 2000, 29.1 billion gallons (110 billion liters) in 2005 and 31.3 billion gallons (118 billion liters) in 2010 (EIA 1993).

Although these regulations currently apply only to on-highway motor fuels, the refinery industry expects that they will be extended to all distillate fuels in the near future (Cambridge Energy Research Associates 1992). If these standards were extended to all distillate fuels, the potential market for biodiesel would roughly double to upwards of 60 billion gallons per year $(7.8$ quadBtu/yr). Inasmuch as the total vegetable oil and tallow supply in the United States (Commodity Research Bureau 1992, United States Department of Agriculture 1992) is currently equivalent to less than 3 billion gallons of biodiesel fuel (0.35 quadBtu/yr), the vegetable oil and tallow supply is insufficient for the fuel market (Fig. 1). The current supply is needed for food and other uses. Assuming the current supply could be increased by $50 \%$ and that amount ( 1.5 billion gallons $=0.17$ quadBtu/yr) could be devoted to fuel use, then only $2 \%$ of the market demand could be supplied by biodiesel from oilseeds. Even that number is not certain as there will be other energy crops competing for land and water resources, such as lignocellulosics for fuel ethanol production (Lynd et al. 1991). A recent estimate for a thirteen state region in the southeastem United States indicate that 0.64 billion gallons (.07 quadBTu/yr) of biodiesel could be produced (Raymer and Van Dyne 1992b). On a global basis the total production of plant and tropical oils, animal fats and marine oils is only about 20 billion gallons (2.6 quadBtu/yr), or about a third of the demand for diesel fuel in the United States. The global supply is for the most part unavailable for use as biodiesel, as it supplies food and other markets. Although the small amount of biodiesel from oilseeds and tallow provides an opportunity to satisfy early market demand, the biofuels industry must have another way to meet the need for these large amounts of diesel fuel. Microalgae provide the opportunity to satisfy much of that need without competing with other technologies and sectors for scarce resources. Biodiesel is ordinarily considered to be derived from oilseeds and animal fats, but a chemically identical biodiesel can be made from microalgae. Microalgal biodiesel would come on line later to fulfill larger market demands from the diesel market, and enhance the long-term potential of biodiesel as a renewable energy source. 


\section{Biodiesel from microalgae}

Microalgae are microscopic aquatic plants with the potential to produce large quantities of lipids (fats and oils). Microalgae are of interest because of their high growth rates and tolerance to varying environmental conditions, and because the oils (lipids) they produce can be extracted and converted to substitute petroleum fuels, such as biodiesel.

Microalgae can be grown in arid and semi-arid regions with poor soil quality where woody or herbaceous crops cannot be grown. Saline water from aquifers or the ocean can be used for growing microalgae. Such water has few competing uses and cannot be used for agriculture, forestry, or as potable water. This technology is complementary to ongoing efforts to grow lignocellulosic biomass in areas with good soil and water resources, because microalgae are projected to be grown in those areas where lignocellulosics or oilseed crops will not grow well (desert southwestern United States and other areas with poor soils). Also, the yield of biomass per acre from microalgae is threefold to fivefold greater than the yield from typical crop plant acreage (Neenan et al. 1986).

Projected global climate change provides another important rationale for this technology. Climate change, which has been linked to the accumulation of excess carbon dioxide in the atmosphere, has the potential of producing economic and geopolitical changes with profound impacts on our economy and the energy industry. Burning fossil fuels, primarily in power plants, is the main contributor to excess carbon dioxide. Inasmuch as the primary nutrient for microalgal growth is carbon dioxide, operation of microalgal biomass farms has emerged as a promising candidate in the search for altemative approaches to capture and dispose of carbon dioxide (Chelf et al. 1993). The microalgae essentially recycle the carbon dioxide from the power plant's stack gases into biodiesel. Although this carbon dioxide is eventually released when the fuel is burned, the process effectively doubles the amount of energy generated for a given quantity of carbon dioxide. Studies show that land and saline water are available in areas such as New Mexico and Arizona to support extensive microalgae facilities. The carbon dioxide emissions from all the power plants in these two states could be trapped by microalgae farms covering about $0.25 \%$ of the total land area. If this technology is expanded to other states, or projected future capacity is brought on line in Arizona and New Mexico, the farms could supply at least 2 quadBtu/yr $(2.1 \mathrm{EJ})$ of energy, and offset an significant amount of carbon dioxide production.

Studies have shown that economic fuel production will require the microalgae to be grown in intensive culture in large outdoor ponds. The system design consists of 6-in $(0.15 \mathrm{~m})$-deep, raceway-shaped ponds with a paddlewheel for circulating the water (Weissman and Tillett 1992). Carbon dioxide (perhaps in the form of power plant stack gases) and other nutrients are injected into the culture to optimize algal growth and oil production. Lipid accumulation is generally triggered by environmental stress, such as depletion of a key nutrient. Current research is directed at a better understanding of ways to trigger lipid accumulation.

\section{Overview of Research}

\section{Description of the Biodiesel from Aquatic Species Project at the National Renewable Energy Laboratory (NREL)}

NREL is managing a project to produce biodiesel fuel from microalgae for the United States Department of Energy (DOE). The primary goal of the Biodiesel/Aquatic Species Project is to develop the technology 
for growing microalgae as a renewable biomass feedstock for the production of a diesel fuel substitute (biodiesel), thereby reducing the need for imported petroleum.

\section{Production}

The NREL culture collection contains microalgal strains that produce large amounts of lipids and grow rapidly, but not necessarily in the same growth phase or in a controllable manner. Genetic techniques are heing used to help reach technical and economic goals of the project, including predictable growth performance and controllable lipid yield.

\section{Extraction and Conversion}

Methods need to be applied to economically extract lipids from microalgae and convert of lipids to hiodiesel. Untreated lipids have oxygen contents and viscosities that are too high to be used in standard engines. The primary goal of the conversion element is to develop methods to economically convert a high proportion of the microalgal lipids to biodiesel fuels, and to improve the overall economics by converting the balance of the biomass to other products.

\section{Engineering Design}

The technology to produce economic liquid fuels from microalgae requires the growth of microalgae on a large scale. Systems to maintain optimal levels of nutrients, carbon dioxide, salinity, and temperature must be developed and tested. The goal of the engineering design element is to develop large-scale outdoor facilities that allow the production goals to be met, and to reduce costs of such a system to those targeted by the project's economic analysis. Future work in this area will hopefully allow the evaluation of various mass-culture and harvesting systems in an effort to increase outdoor algal productivities and decrease the cost of operating such a facility.

\section{Analysis}

Economic and resource analyses provide input to project management to set research directions and priorities. The goal of the analysis element is to support the technology development by determining cost goals, economic sensitivities, resource assessments, and environmental impacts as new data are developed. To accomplish this, researchers will conduct ongoing economic analyses. Resource and environmental assessments will be conducted to identify potential constraints, identify and address data gaps, and provide project guidance.

\section{Project Accomplishments}

Progress has been made in several areas that are important to the Biodiesel from Aquatic Species Project. Initial research in the project involved a large effort to collect algal species from natural habitats, followed by an extensive screening process to determine which of the collected strains were able to tolerate the expected mass culture conditions and to produce large quantities of lipids (Barclay et al. 1987). This effort led to the establishment of an extensive microalgal culture collection that provides NREL investigators with a large gene pool for additional study and manipulation.

Another area of research in the project was the operation of an Outdoor Test Facility in Roswell, New 
Mexico to carry out an engineering design assessment (Weissman and Tillett 1989). Two 0.1 hectare ponds were operated successfully, providing substantial information regarding microalgal growth rates in mass culture, carbon dioxide utilization, and pond design parameters (Weissman and Tillett 1992). During this period, research was also conducted into various means of lipid extraction and conversion to biodiesel (Nagle et al. 1988, Nagle and Lemke 1990).

Recent research efforts have concentrated on applying genetic methods to microalgae (Brown et al. 1990). DNA from microalgae with potential for fuel production has been analyzed chemically (Jarvis et al. 1992), and short-term expression of a foreign genes such as firefly luciferase was achieved (Jarvis and Brown 1991). Progress has also been made with respect to the development of new protocols for introducing foreign genes into microalgae (Dunahay 1993). In the area of microalgal lipid biochemistry and molecular biology, an important enzyme in lipid metabolism, acetyl-CoA carboxylase was purified (Roessler 1990). This purified enzyme aided efforts to clone and sequence this key gene in lipid metabolism (Roessler and Ohlrogge 1993).

\section{Acknowledgements}

This work is supported by the Biofuels Systems Division of the U. S. Department of Energy. Critical reading of the manuscript and helpful suggestions by E. Jarvis and J.C. Schneider are gratefully appreciated. V. Putsche provided some of the analyses on impacts of the 1990 CAAA.

\section{References}

Barclay, W.R., K.L. Terry, N.J. Nagle, J.C. Weissman, and R.P. Goebel. 1987. "Potential of new strains of marine and inland saline-adapted microalgae for aquaculture". J. World Aquaculture Soc. 18:218-228.

Brown, L. M. T. G. Dunahay and E. E. Jarvis. 1990. "Applications of Genetics to Microalgae Production." Devel. Ind. Microbiol. 31:271-274.

Cambridge Energy Research Associates (CERA). 1992. "The U.S. Refining Industry: Facing the Challenges of the 1990s," Prepared for the U.S. Department of Energy, January.

Chelf, P., L. M. Brown and C. E. Wyman. 1993. "Aquatic biomass resources and carbon dioxide trapping." Biomass Bioenerg. 4:175-183.

Clements, D. 1992. "Biodiesel Working Group" in Proceeding of "Technology for Expanding the Biofuels Industry, April 21-22, 1992, Chicago Ill." U. S. Department of Energy, US Department of Agriculture, Renewable Fuels Association. pp. V-1-V-3.

Commodity Research Bureau. 1992. 1992 CRB Commodity Year Book, New York: Knight-Ridder Financial Publishing.

Dunahay, T. G. 1993. "Transformation of Chlamydomonas reinhardtii with silicon carbide whiskers" Biotechniques (in press). 
Energy Information Administration (EIA) (1992), "Annual Energy Review", Office of Markets and End Use, U.S. Department of Energy, Washington DC, DOE/EIA-0384(91).

Energy Information Administration (EIA) 1993, "Annual Energy Outlook," Office of Integrated Analysis and Forecasting, U.S. Department of Energy, Washington DC, DOE/EIA-0383(93), January.

Feinberg, D. and M. Karpuk 1990. "COO - sources for microalgae-based liquid fuel production." SERI/TP-232-3820. Solar Energy Research Institute., Golden, CO. 35 pp.

Jarvis, E. E. and L. M. Brown 1991. "Transient expression of firefly luciferase in protoplasts of the green alga Chlorella ellipsoidea." Curr. Gen. 19: 317-321.

Jarvis, E. E., T. G. Dunahay and L. M. Brown. 1992. "DNA nucleoside composition and methylation in four classes of microalgae." J. Phycology 28:356-362

Lynd, L. R., J. H. Cushman, R. J. Nichols and C. E. Wyman. 1991. "Fuel Ethanol from Cellulosic Biomass." Science 251:1318-1323.

N. Nagle, P. Chelf, P. Lemke and W. Barclay. 1988. "Conversion of lipids through biological pretreatment" Proceedings of Energy from Biomass and Waste XII, Feb. 15-19, 1988, Institute of Gas Technology. Chicago, IL.

Nagle , N. and P. Lemke. 1990. "Production of methyl ester fuel from microalgae." Appl. Biochem. Biotechnol. 24/25:355-361.

Neenan, B., Feinberg, D., Hill, A., McIntosh, R., and K. Terry. 1986. Fuels from Microalgae: Technology Status, Potential, and Research Requirements. SERI/SP-231-2550, Solar Energy Research Institute, Golden, CO. 149 pp.

Raymer, P. L. and D. L. Van Dyne. 1992a. Biodiesel production potential from industrial rapeseed in the Southeastern $U$. S. Southeastem Regional Biomass Program, Tennessee Valley Authority, Muscle Shoals, AL. Report \#TV-86444V, 20 pp.

Raymer, P. L. and D. L. Van Dyne. 1992b. "Potential of oilseed rape for biodiesel production in the Southeastem U. S. A." in Cundiff, J. S. Liquid Fuels from Renewable Resources" American Society of Agricultural Engineers, St. Joseph, Michigan. pp. 132-144.

Roessler, P. G., 1990, "Purification and Characterization of Acetyl-CoA Carboxylase from the Diatom Cyclotella cryptica," Plant Physiology, 92:1, pp. 73-78.

Roessler, P. and J. Ohlrogge. 1993. "Cloning and characterization of the gene that encodes acetyl-CoA carboxylase in the alga Cyclotella cryptica" J. Biol. Chem. (in press)

United States Department of Agriculture. 1992. Agricultural Statistics 1992. U. S. Government Printing Office, Washington, DC.

Weissman, J. C. and Tillett, D. M. 1992. "Design and operation of an outdoor microalgae test facility: 
Large- scale system results." In Brown, L. M. and S. Sprague, Aquatic Species Project Report, Jan. 1992. NREL MP-232-4174, pp. 32-56. National Renewable Energy Laboratory, Golden, CO.

Weissman, J. C. and Tillett, D. M. 1992. "Design and operation of an outdoor microalgae test facility." In Bollmeier, W. S. and S. Sprague, Aquatic Species Program Annual Report, September 1989. SERI/SP' 2321-3579. Solar Energy Research Institute, Golden, CO. 